Research Article

\title{
The Influence of Executive Compensation Gap on Earnings Management from the Perspective of Media Supervision: Evidence from China
}

\author{
Ye Wang $(\mathbb{D}$, Fusheng Wang $(\mathbb{D}$, and Shiyu Liu $(\mathbb{D}$ \\ Department of Accounting, School of Management, Harbin Institute of Technology, Harbin 150001, China \\ Correspondence should be addressed to Fusheng Wang; samliu@hit.edu.cn
}

Received 6 August 2021; Revised 24 August 2021; Accepted 25 August 2021; Published 2 September 2021

Academic Editor: Daqing Gong

Copyright (c) 2021 Ye Wang et al. This is an open access article distributed under the Creative Commons Attribution License, which permits unrestricted use, distribution, and reproduction in any medium, provided the original work is properly cited.

\begin{abstract}
To pursue higher compensation, the agent's earnings management behavior may damage the principal's interests. Can managers whose compensation reaches the expected level seek benefits for the company through earnings management? This study takes China's A-share listed companies from 2014 to 2018 as samples. The conclusions show that managers with higher compensation levels will carry out earnings management in favor of the company while taking their own interests into consideration. For companies with stronger profitability, the higher the managers' compensation is, the more they are inclined to reduce accrued earnings in the current period to further reduce taxes and fees. For companies with weaker profitability, managers with higher compensation tend to choose to increase real earnings to further optimize financial indicators. It has been found through further research that high pressure generated by media attention can make well-paid executives restrain the above earnings management behavior, which serves as an effective method to protect investors' rights and interests.
\end{abstract}

\section{Introduction}

According to the principal-agent theory, the conflict of interest between listed company, the principals, and its manager, the agents, is a real problem in corporate governance. Earnings management refers to the process that managers take advantage of the separation of ownership and management rights of listed companies to maximize their private interests by manipulating financial indicators without violating laws and regulations or to maximize their own interests or the company's stock price by using different accounting policies without violating accounting standards [1]. Existing studies usually assume that the decision-makers of the above earnings management behavior are rational people, and the ultimate goal of rational decision-makers is to maximize their own interests, not the interests of the company. However, if the self-interest of the managers of listed companies can be met, or have reached the expectation, will the managers make the "irrational" decision to maximize the company's profits, that is, will they choose the earnings management behavior that is beneficial to the company?

Taking all A-share listed companies in China from 2014 to 2018 as the research object, this paper studies the impact of executive compensation gap on earnings management and further studies whether media supervision can play an effective governance role. The empirical results show that the higher the executive compensation gap of listed companies, the higher the degree of earnings management. Specifically, for companies with strong profitability, high-paid managers are more likely to reduce accrued earnings management downwards to save taxes, while for companies with weak profitability, high-paid managers are more inclined to upward increase earnings management on real activity to beautify the financial index. Further research shows that the market pressure generated by media attention can make the well-paid managers restrain their earnings management level, which is an effective governance method to protect investors' rights and interests from infringement. 
The academic contributions of this paper are as follows. First, it makes a beneficial supplement to the existing compensation motivation theory of earnings management, enriches and improves the theoretical research on the influence mechanism of executive compensation on earnings management, and finds that managers whose compensation meets expectations are more likely to make decisions conducive to the interests of the company. Second, from the perspective of corporate profitability, it fills the theoretical gap of the impact of managers' compensation gap on their earnings management decisions. Third, it reveals the effective governance role of media attention in the impact of executive compensation gap on earnings management.

\section{Literature Review}

There is a close correlation between executive compensation and company performance, and company performance and its fluctuation degree create the space for managers to manage earnings. Xu et al. [2], through the study on the salary differences of the senior management team of 1740 companies in the A-share market of Shanghai and Shenzhen stock markets from 2007 to 2011, found that the larger the executive salary gap, the higher the degree of performance fluctuation of the company. In addition, lower-level executives tend to make riskier decisions in order to achieve better performance and thus get higher pay or promotion. Subsequently, Liu and Wan [3] further divided the listed companies in the sample into state-owned and non-stateowned companies. In comparison, the executive compensation gap of state-owned listed companies has a lower impact on corporate performance, while the executive compensation gap of non-state-owned listed companies is still positively correlated with corporate performance.

The psychology of salary comparison is also one of the important reasons to induce executives to carry out earnings management. Luo et al. [4] found that executives of listed companies whose salaries are lower than the average of the same industry usually have psychology of comparison, which leads them to manipulate the company's financial information to significantly improve the company's earnings, so as to gain the company's recognition and trust. When the competitiveness of the company is low, the executives are more likely to directly choose the real earnings management with higher risk rather than the hidden accrual earnings management. Yuan et al. [5] explained this phenomenon. The reason is that the real earnings management behavior makes the interest convergence effect of executive incentive far more than the opportunistic behavior. In addition, when the company's financial indicators are not easy to be manipulated, the board of directors is more likely to directly recruit executives from outside to manipulate earnings [6]. External CEOS with lower compensation may show stronger negative emotions, leading to a decrease in earnings management behaviors [7].

Executives compete with each other for higher pay or better promotion opportunities. Managers who have earned higher salaries are usually more loyal to the company, and managers with higher loyalty will benefit the company by making decisions that benefit the company's growth [8]. In other words, the higher loyalty of managers is, the more likely earnings management behaviors are to benefit the company's earnings. In foreign countries, executives of listed companies are more willing to adjust profits and losses of nontaxable items to reduce tax costs in order to minimize the cost of expensive corporate income tax. If the company's net profit is higher than the upper limit of earnings or lower than the lower limit of earnings, the management has an incentive to reduce the current profit to avoid taxes payable in the current or future periods. However, if the company's net profit is between the upper and lower bounds of earnings, management is more inclined to increase the profit to obtain higher compensation [9]. In China, Wang et al. [10] and Li et al. [11] successively found that no matter how the policy adjusts the tax rate, the earnings management degree of listed companies is significantly improved compared to before the tax rate changes. In the case of tax avoidance, companies are more inclined to choose the covert means of earnings management of downward reduction accruals to control earnings, so as to avoid being questioned or punished by regulatory authorities [12]. Moreover, with the increase of the pay gap between executives and other managers of listed companies, its influence and status will be significantly increased, and the manager's overconfidence degree also subsequently rises. Overly optimistic highly paid managers tend to make more risky decisions in order to meet market expectations, which can also lead to the increase of the degree of earnings management [13]. In a word, whether motivated by tax avoidance or aggressive strategy, well-paid managers can significantly affect the degree of earnings management of executives.

\section{Theoretical Analysis and Hypothesis}

By reviewing the existing literature, we can conclude three theoretical mechanisms of executive pay gap affecting earnings management of listed companies.

First, the executive pay gap can cause the fluctuation of company performance. According to the tournament theory, increasing the pay gap with other executives can effectively reduce the cost of monitoring managers for company owners. In the contractual relationship, the consistency of the interests of the principal and the agent will therefore get the same incentive, which ultimately improves the performance level of the company and then creates a realistic foundation for the space of earnings management: the higher the performance of listed companies, the more room for management to adjust earnings.

Second, executive compensation comparison can induce earnings management. The existing research on earnings management usually assumes that the decision-maker of earnings management behavior is rational person, and the ultimate goal of rational decision-maker is to maximize their own interests, rather than the maximization of corporate profits. Lower-level executives usually play the role of riskprone in order to improve the company's performance in order to get promoted. If the performance target is not 
achieved, it may choose more earnings management behavior and more aggressive earnings management methods.

Third, executive compensation incentives will induce earnings management. The essence of earnings management is the agent's adjustment of the company's financial information disclosure strategy. According to the theory of compensation incentive, compensation incentive is one of the basic motivations of earnings management of Chinese listed companies. Only by promoting the competition among senior executives can the tournament theory play a motivational effect so that the management level and ability of managers can be stimulated. In order to achieve the desired goal, executives who are motivated by compensation may make favorable business decisions, which reduces the possibility of "free riding" or slacking off. Active executives can improve current performance through earnings management to achieve contractual goals.

Through the above path theory analysis, it is not difficult to see that there is a significant impact between the executive compensation gap and earnings management. The higher the executive's relative compensation level is, the easier it is to carry out earnings management. The existing earnings management is divided into accrual item earnings management and real activity earnings management. Compared with accrual earnings management, real earnings management is more hidden, but it does harm to the long-term interests of the company. Based on the above analysis, this paper proposes a research Hypothesis 1 to be tested.

Hypothesis 1. Executive compensation gap is positively correlated with earnings management degree of listed companies.

The pay gap of executives is positively correlated with their overconfidence [13]. When overconfident managers make decisions, they will ignore factors that contradict their beliefs and underestimate information risks. Therefore, the salary level can significantly affect the loyalty of executives, and the salary gap can effectively stimulate the enthusiasm and management efficiency of executives. First and the foremost, according to Maslow's hierarchy of needs theory, self-actualization is regarded as the highest level of needs. If self-actualization needs are satisfied, managers may lose the motivation to manipulate earnings for their own interests, so as to adjust earnings in favor of the company. In addition, under the effect of tax avoidance motivation, for listed companies with strong profitability, if the compensation can meet the expected level, senior managers have a strong incentive to avoid tax for the company. High-paid managers may reduce the high taxes and fees caused by higher profits by the way of negative earnings management. Lastly, under the effect of market pressure and reputation mechanism, for listed companies with weak profitability, if the compensation can meet the expected level, senior managers have a strong motivation to positively increase the current earnings to maintain their own reputation and image or meet market expectations. Based on the above analysis, this paper proposes the research Hypothesis 2 and 3 to be tested.

Hypothesis 2. For companies with strong profitability, the higher the executive compensation gap, the more inclined they are to conduct negative earnings management.

Hypothesis 3. For companies with weak profitability, the higher the executive compensation gap, the more inclined they are to carry out positive earnings management.

\section{Research Design}

4.1. Sample Selection and Data Sources. This paper selects all A-share listed companies in Shanghai and Shenzhen stock markets from 2014 to 2018 as research samples. After excluding the financial industry, ST, and $*$ ST companies, 11,653 observation data of 2,825 companies were finally obtained. Data from CSMAR database was processed and analyzed using STATA.

\subsection{Variable Definition and Measurement}

4.2.1. Measurement of Accrual Earnings Management. In this paper, referring to the treatment method of Jones model by Wang et al. [14], the cross-sectional correction of Jones model is selected to calculate the accounting earnings management level $\mathrm{ABSDA}_{i, t}$ as the proxy variable of earnings management. Firstly, the sample companies were grouped according to the industry classification issued by the China Securities Regulatory Commission. Model (1) was used to perform multiple linear regression for each group of samples, and the regression coefficient was obtained by the least square method. Secondly, the regression coefficient obtained is substituted into model (2) to obtain the expected accrual profit $\mathrm{NA}_{i, t}$ of each company in its industry. Among them, the $\mathrm{TA}_{i, t}$ represents the total accrued profit of company $i$ in $t$ years; $\Delta S_{i, t}$ is the differences between the operating revenue of company $i$ in $t$ years and the sales revenue in $t-1$ years; $\mathrm{PPE}_{i, t}$ is the original value of fixed assets at ethe end of yar $t$ of company $i ; \mathrm{IA}_{i, t}$ is the sum of intangible assets and other noncurrent assets of ${ }_{i}$ company in $t$ years; $A_{i, t-1}$ is the total assets of company $i$ at the end of $t-1$ years; $\Delta \mathrm{AR}_{i, t}$ represents the differences between the total items receivable in $t$ year and $t-1$ year of company $i$. Finally, model (3) is used to calculate the difference $\mathrm{DA}_{i, t}$ between actual accruals and expected accruals of the company. $\mathrm{DA}_{i, t}>0$ indicates positively adjusted accrued earnings management, and $\mathrm{DA}_{i, t}<0$ indicates a negative adjustment to accrued earnings management. The greater the absolute value $\mathrm{ABSDA}_{i, t}$ of $\mathrm{DA}_{i, t}$ is, the higher the degree of accrual earnings management of the company is: 


$$
\begin{aligned}
& \frac{\mathrm{TA}_{i, t}}{A_{i, t-1}}=\alpha_{0} \frac{1}{A_{i, t-1}}+\alpha_{1} \frac{\Delta S_{i, t}}{A_{i, t-1}}+\alpha_{2} \frac{\mathrm{PPE}_{i, t}}{A_{i, t-1}}+\alpha_{3} \frac{\mathrm{IA}_{i, t}}{A_{i, t-1}}+\varepsilon_{i, t}, \\
& \mathrm{NA}_{i, t}=\alpha_{0} \frac{1}{A_{i, t-1}}+\alpha_{1} \frac{\left(\Delta S_{i, t}-\Delta \mathrm{AR}\right)_{i, t}}{A_{i, t-1}}+\alpha_{2} \frac{\mathrm{PPE}_{i, t}}{A_{i, t-1}}+\alpha_{3} \frac{\mathrm{IA}_{i, t}}{A_{i, t-1}}, \\
& \mathrm{DA}_{i, t}=\frac{\mathrm{TA}_{i, t}}{A_{i, t-1}}-\mathrm{NA}_{i, t} .
\end{aligned}
$$

4.2.2. Measurement of Real Activity Earnings Management. Roychowdhury [15] proposed real earnings management based on abnormal operating activity cash flow REM_CFO, abnormal production cost REM_PROD, and abnormal expenses REM_DISX three phenomena, proposed to quantify the true earnings management degree of the index REM. Firstly, (4) is used to regression of all samples in the same industry in the same year, and the residual is the cash flow of abnormal operating activities. CFO is cash flow from operating activities in the current period. $S_{i, t}$ is current sales volume. $A_{i, t-1}$ is the total asset size of one phase behind. Then, using (5) and (6) in the same way, the abnormal production costs and abnormal expenses are estimated, where PROD is the total production cost of the current period, equal to the sum of current operating cost and current inventory changes. DISX is the total expenses of the current period, equal to the sum of selling expenses and administrative expenses:

$$
\begin{aligned}
\frac{\mathrm{CFO}_{i, t}}{A_{i, t-1}} & =\beta_{1} \frac{1}{A_{i, t-1}}+\beta_{2} \frac{S_{i, t}}{A_{i, t-1}}+\beta_{3} \frac{\Delta S_{i, t}}{A_{i, t-1}}+e_{1}, \\
\frac{\mathrm{PROD}_{i, t}}{A_{i, t-1}} & =\beta_{4} \frac{1}{A_{i, t-1}}+\beta_{5} \frac{S_{i, t}}{A_{i, t-1}}+\beta_{6} \frac{\Delta S_{i, t}}{A_{i, t-1}}+\beta_{7} \frac{\Delta S_{i, t-1}}{A_{i, t-1}}+e_{2},
\end{aligned}
$$

$$
\frac{\operatorname{DISX}_{i, t}}{A_{i, t-1}}=\beta_{8} \frac{1}{A_{i, t-1}}+\beta_{9} \frac{S_{i, t-1}}{A_{i, t-1}}+e_{3} .
$$

According to theoretical analysis, these three indicators have different directions, so formula (5) is used to integrate the real earnings management degree index REM. REM ${ }_{i}$, ${ }_{t}>0$ indicates the positive adjustment of real earnings management, and $\mathrm{REM}_{i, t}<0$ indicates the negative adjustment of real earnings management. In addition, the greater the absolute value $\mathrm{ABSREM}_{i, t}$ of $\mathrm{REM}_{i, t}$ is, the higher the degree of real activity earnings management is:

$$
\mathrm{REM}_{i, t}=\mathrm{REM}_{-} \mathrm{PROD}_{i, t}-\mathrm{REM}_{-} \mathrm{CFO}_{i, t}-\mathrm{REM}_{-} \mathrm{DISX}_{i, t} .
$$

4.2.3. Measurement of Executive Compensation Gap. In the internal competition environment, the larger the pay gap between the executive and other managers, the higher the relative pay, and the more likely it is to reach the expected compensation level. This article draws lessons from Jiang et al. [13], the top three executives in listed companies are regarded as a team, and the ratio of their total compensation to the total compensation of all executives is calculated as a proxy variable for the executive compensation gap. The higher the manager's relative salary is, the more satisfied the manager's salary expectation is, and the weaker his motivation for earnings management is.

4.2.4. Other Control Variables. In addition, this paper also controls other variables that affect earnings management, and controls the annual and industry effects. The specific variable definitions and measurement methods are shown in Table 1 .

4.3. Model Design. In order to test the impact of executive compensation on accrued item earnings management and real activity earnings management, the basic regression model is set as follows:

$$
\begin{aligned}
\mathrm{EM}= & \beta_{0}+\beta_{1} \mathrm{RP}+\beta_{2} \mathrm{ROA}+\beta_{3} \mathrm{TOBINQ}+\beta_{4} \mathrm{SIZE}+\beta_{5} \mathrm{GROWTH}+\beta_{6} \mathrm{LEV}+\beta_{7} \mathrm{TOP} \\
& +\beta_{i} \mathrm{INDUSTRY}+\beta_{j} \text { YEAR }+\varepsilon .
\end{aligned}
$$

In this regression model, the coefficients of the equation are determined by the ordinary least squares. If the regression model is statistically significant, and the coefficient $\beta_{1}$ of RP is positive; it indicates that managers with relatively higher salaries have higher motivation for earnings management. In addition, in order to test the differences of earnings management behaviors of well-paid managers in companies with different profitability, this paper introduces the interaction term $\mathrm{RP} \times \mathrm{ROA}$ into the above regression model to test whether corporate profitability ROA has a moderating effect on the process of executive compensation affecting earnings management:

$$
\begin{aligned}
\mathrm{EM}= & \beta_{0}+\beta_{1} \mathrm{RP}+\beta_{2} \mathrm{RP} \times \mathrm{ROA}+\beta_{3} \mathrm{ROA}+\beta_{4} \mathrm{TOBINQ}+\beta_{5} \mathrm{SIZE}+\beta_{6} \mathrm{GROWTH} \\
& +\beta_{7} \mathrm{LEV}+\beta_{8} \mathrm{TOP}+\beta_{i} \mathrm{INDUSTRY}+\beta_{j} \mathrm{YEAR}+\varepsilon .
\end{aligned}
$$


TABLE 1: Definitions of major variables.

\begin{tabular}{|c|c|c|}
\hline The variable name & $\begin{array}{l}\text { Variable } \\
\text { symbol }\end{array}$ & Variable definitions \\
\hline & DA & Accrual item earnings management is calculated according to models (1)-(3) \\
\hline Earnings & REM & Real activity earnings management, calculated according to models (4)-(7) \\
\hline management & ABSDA & The absolute value of accrual earnings management DA \\
\hline & ABSREM & The absolute value of REM managed by real activity earnings \\
\hline Executive pay gap & $\mathrm{RP}$ & $\begin{array}{c}\text { The combined compensation of the top three highest-paid executives is compared with that of all } \\
\text { executives }\end{array}$ \\
\hline $\begin{array}{l}\text { Corporate } \\
\text { profitability }\end{array}$ & ROA & Return on total assets, the ratio of net income to average total assets \\
\hline The enterprise value & TOBINQ & TOBINQ is the ratio of the market value to the total assets at the end of the year \\
\hline The company size & SIZE & The natural log of total assets at year-end \\
\hline Company growth & GROWTH & The annual growth rate of operating revenue \\
\hline $\begin{array}{l}\text { Financial leverage } \\
\text { ratio }\end{array}$ & LEV & Ratio of total liabilities to total assets \\
\hline If the big four & BIG4 & Is the accounting firm a big four? If yes, take 1 , otherwise take 0 \\
\hline Industry & INDUSTRY & $\begin{array}{c}\text { Industry dummy variable generated according to industry classification standard of China } \\
\text { securities regulatory commission }\end{array}$ \\
\hline The annual & YEAR & Annual dummy variable \\
\hline
\end{tabular}

\section{Empirical Results and Analysis}

5.1. Descriptive Statistics. Table 2 reports the descriptive statistical analysis results, in which managers pay levels relatively maximum of $\mathrm{RP}$ is 0.775 , and the minimum value is 0.116 , indicating that China's listed companies pay the sum of three former executives of all executive pay is as high as $77.5 \%$, only $11.6 \%$ minimum. A preliminary explanation of listed companies in our country has certain compensation gap, to verify the existence of "pay mess." There is an obvious gap between the maximum and minimum values of accrual item earnings management DA and real activity earnings management REM. Therefore, it is of great practical significance to discuss not only the degree of earnings management but also the direction of earnings management in the research process. In addition, Pearson and Spearman correlation tests were also carried out for the main variables in this paper, but the correlation matrix was not reported in the text due to space limitations.

5.2. Regression Analysis of Executive Compensation Gap and Earnings Management. Table 3 reports the regression results of executive compensation gap and earnings management. The results of column (1) show that the regression model is significant, and the coefficient of executive compensation gap RP is 0.027 , which is significantly positive at the level of 0.01 , indicating that the executive compensation gap is positively correlated with earnings management of accrued items. In other words, the higher the executive compensation gap, the greater the degree of accrual earnings management. The results of column (2) show that the regression model is significant, and the coefficient of RP of executive compensation gap is 0.080 , which is significantly positive at the level of 0.01 , indicating that the executive compensation gap is positively correlated with the real activity earnings management; that is, the higher the executive compensation gap is, the greater the degree of accrual earnings management of managers is. In conclusion, the higher executive compensation is, the easier earnings management is for them, which supports the research Hypothesis 1.

5.3. Regression Analysis under ROA Group. The higher the executive pay is, the more inclined to how to adjust the current accounting surplus it is. In order to test Hypothesis 2 of this paper, we centralize the sample companies according to the index ROA that describes profitability and divide them into high profitability group and low profitability group to test whether there is a correlation between executive pay gap and the direction of earnings management. As shown in column (1) of Table 4, the coefficient of RP of the compensation level of the high capability group $\left(C_{-}\right.$ROA $\left.>0\right)$ is -0.017 , which is significantly negative at the level of 0.1 . The executive compensation gap is negatively correlated with accrual earnings management. It shows that when the company's profits are strong, high-paid executives are more inclined to carry out negative accrual earnings management rather than real activity earnings management. This paper considers that real activity earnings management, which can harm the company's interests in the long term, should not be adopted, which supports Hypothesis 2 in this paper. The empirical results are consistent with Luo and Zeng [16] and others' conclusion that "salary comparison will promote executives to avoid tax for the company by downward adjusting accrued earnings management, but the evidence of adjusting real earnings management is very weak." As shown in column (4), the coefficient of RP of the compensation level of the high capability group $\left(\mathrm{C} \_\right.$ROA $>0$ ) is 0.048 , which is significantly positive at the level of 0.05 . The executive compensation gap is positively correlated with accrual earnings management. It shows that when corporate earnings are weak, high-paid executives are more inclined to carry out positive real activity earnings management rather than accrual earnings management. This paper considers that the disclosure of financial information 
TABLE 2: Descriptive statistics of main variables.

\begin{tabular}{|c|c|c|c|c|c|c|}
\hline Variables & Sample size & The mean & The standard deviation & The minimum & The median & The maximum \\
\hline $\mathrm{DA}$ & 11653 & 0.004 & 0.128 & 2.349 & 0.003 & 4.869 \\
\hline REM & 11653 & 0.047 & 0.257 & 5.099 & 0.041 & 3.673 \\
\hline $\mathrm{RP}$ & 11653 & 0.420 & 0.119 & 0.116 & 0.404 & 0.775 \\
\hline ROA & 11653 & 0.038 & 0.098 & 1.859 & 0.036 & 7.249 \\
\hline TOBINQ & 11653 & 2.698 & 2.749 & 0.687 & 2.022 & 122.191 \\
\hline SIZE & 11653 & 22.355 & 1.300 & 17.641 & 22.181 & 28.52 \\
\hline GROWTH & 11653 & 0.223 & 1.647 & 0.982 & 0.105 & 87.484 \\
\hline LEV & 11653 & 0.430 & 0.204 & 0.009 & 0.420 & 1.687 \\
\hline BIG4 & 11653 & 0.057 & 0.232 & 0 & 0 & 1 \\
\hline
\end{tabular}

TABLE 3: Regression results of executive compensation gap and earnings management.

\begin{tabular}{lcc}
\hline Variables & $(1)$ & $(2)$ \\
& ABSDA & ABSREM \\
\hline \multirow{2}{*}{ RP } & $0.027^{* * *}$ & $0.080^{* * *}$ \\
& $(3.20)$ & $(5.11)$ \\
\hline \multirow{2}{*}{ ROA } & $0.215^{* * *}$ & $0.304^{* * *}$ \\
& $(20.92)$ & $(16.05)$ \\
\hline \multirow{2}{*}{ TOBINQ } & $0.001^{* * *}$ & $0.012^{* * *}$ \\
& $(3.29)$ & $(15.20)$ \\
\hline \multirow{2}{*}{ SIZE } & $0.010^{* * *}$ & $0.007^{* * *}$ \\
& $(9.46)$ & $(3.38)$ \\
\hline \multirow{2}{*}{ GROWTH } & $0.006^{* * *}$ & $0.013^{* * *}$ \\
& $(11.15)$ & $(11.84)$ \\
\hline \multirow{2}{*}{ LEV } & $0.113^{* * *}$ & 0.017 \\
& $(18.95)$ & $(1.54)$ \\
\hline \multirow{2}{*}{ BIG4 } & $0.012^{* * *}$ & 0.005 \\
& $(2.65)$ & $(0.63)$ \\
\hline INDUSTRY & Yes & Yes \\
YEAR & Yes & Yes \\
Constant & $0.245^{* * *}$ & $0.083^{*}$ \\
& $(10.00)$ & $(1.84)$ \\
Adj. $R^{2}$ & 11653 & 11653 \\
\hline & 0.100 & 0.115 \\
\hline
\end{tabular}

Note. ${ }^{*},{ }^{* *}$, and ${ }^{* * *}$ indicate significance at the confidence level of $10 \%, 5 \%$, and $1 \%$, respectively, and $t$-value statistics are in parentheses.

is adjusted to beautify the company's financial report to meet market expectations, which preliminarily supports $\mathrm{Hy}-$ pothesis 3 in this paper. The research conclusion shows that if the executive compensation level of listed companies can reach the expected goal, they will choose the disclosure strategy of accounting information that is favorable to the company.

5.4. Analysis of the Regulatory Effect of Profitability. In order to more accurately test the effect of corporate profitability on the impact of executive compensation on earnings management, we introduce ROA into the basic model and get the regression model (9). The regression result of column (1) in Table 5 shows that the regression coefficient of interaction term $\mathrm{RP} \times \mathrm{ROA}$ is 0.758 , which is significantly negative at the level of 0.01 , indicating that corporate profitability ROA can negatively regulate the role of compensation level and earnings management of accrued items. In other words, corporate profitability can inhibit the negative adjustment of high-paid managers to earnings management of accrued items. Similarly, the regression results of column (2) show that the regression coefficient of interaction term $\mathrm{RP} \times \mathrm{ROA}$ is -2.104 , which is significantly negative at 0.01 level, indicating that corporate profitability ROA can negatively adjust the effect of salary level on real active earnings management; that is, corporate profitability can inhibit the positive adjustment of high salary managers on real active earnings management. The research conclusion once again supports the research Hypotheses 2 and 3 in this paper. It is reasonable to increase the managers' compensation of listed companies, in order to optimize the conflicts of interest between owners and managers. As a result, managers can adjust the external disclosure strategy of accounting information for the purpose that is beneficial to the development of the company.

5.5. Robustness Test. The above analysis has fully verified the impact of executive compensation gap on earnings management. For the sake of the robustness of the results, this paper uses the modified Jones model [17] and the extended Jones model [18] with the performance variable ROA as the proxy variables of earnings management to re-carry out regression analysis according to the abovementioned method. Due to the limited space of the article, the test results were not reported in this paper, and the sign and significance of the regression coefficient were unchanged, indicating that the empirical results in this paper have good robustness.

5.6. Further Research. Under the background of China's special economic market system, in recent years, the disorder of the executive compensation of listed companies has attracted the attention of China's regulatory authorities. While executives of public companies can earn huge salaries, shareholders receive nothing in dividends. Media governance, as a restriction mechanism outside laws and regulations, can effectively prevent companies from infringing on investors' rights and interests by exposing bad behaviors of companies [19] or directly cause administrative intervention of regulatory authorities [20]. From the perspective of effective supervision theory, market media and policy media should show remarkable governance effects in the management of the high salary disorder of listed companies. 
TABLE 4: Regression results of grouping comparison of profitability.

\begin{tabular}{|c|c|c|c|c|}
\hline \multirow[b]{2}{*}{ Variables } & \multicolumn{2}{|c|}{ C_ROA $>0$} & \multicolumn{2}{|c|}{ C_ROA $<0$} \\
\hline & $\begin{array}{l}(1) \\
\mathrm{DA}\end{array}$ & $\begin{array}{c}(2) \\
\text { REM }\end{array}$ & $\begin{array}{l}(3) \\
\text { DA }\end{array}$ & $\begin{array}{c}(4) \\
\text { REM }\end{array}$ \\
\hline $\mathrm{RP}$ & $\begin{array}{c}0.017^{*} \\
(1.68) \\
\end{array}$ & $\begin{array}{l}0.015 \\
(0.45) \\
\end{array}$ & $\begin{array}{l}0.013 \\
(1.05) \\
\end{array}$ & $\begin{array}{c}0.048^{* *} \\
(2.03)\end{array}$ \\
\hline TOBINQ & $\begin{array}{l}0.001 \\
(0.75)\end{array}$ & $\begin{array}{c}0.017^{* * *} \\
(10.55)\end{array}$ & $\begin{array}{l}0.001 \\
(1.02)\end{array}$ & $\begin{array}{c}0.005^{* * *} \\
(4.40)\end{array}$ \\
\hline SIZE & $\begin{array}{l}0.002 \\
(1.20)\end{array}$ & $\begin{array}{c}0.040^{* * *} \\
(9.05)\end{array}$ & $\begin{array}{c}0.010^{* * *} \\
(6.66)\end{array}$ & $\begin{array}{l}0.005 \\
(1.63) \\
\end{array}$ \\
\hline GROWTH & $\begin{array}{c}0.005^{* * *} \\
(7.54)\end{array}$ & $\begin{array}{c}0.013^{* * *} \\
(4.93)\end{array}$ & $\begin{array}{c}0.001^{*} \\
(1.81)\end{array}$ & $\begin{array}{c}0.009^{* * *} \\
(6.24)\end{array}$ \\
\hline LEV & $\begin{array}{c}0.020^{* * *} \\
(2.64)\end{array}$ & $\begin{array}{c}0.296^{* * *} \\
(10.96)\end{array}$ & $\begin{array}{c}0.069^{* * *} \\
(8.30)\end{array}$ & $\begin{array}{c}0.132^{* * *} \\
(8.62) \\
\end{array}$ \\
\hline BIG4 & $\begin{array}{c}0.022^{* * *} \\
(4.04)\end{array}$ & $\begin{array}{c}0.037^{* *} \\
(2.09) \\
\end{array}$ & $\begin{array}{c}0.021^{* * *} \\
(3.21)\end{array}$ & $\begin{array}{c}0.023^{*} \\
(1.86) \\
\end{array}$ \\
\hline $\begin{array}{l}\text { INDUSTRY } \\
\text { YEAR }\end{array}$ & $\begin{array}{l}\text { Yes } \\
\text { Yes }\end{array}$ & $\begin{array}{l}\text { Yes } \\
\text { Yes }\end{array}$ & $\begin{array}{l}\text { Yes } \\
\text { Yes }\end{array}$ & $\begin{array}{l}\text { Yes } \\
\text { Yes }\end{array}$ \\
\hline Constant & $\begin{array}{l}0.029 \\
(0.95) \\
\end{array}$ & $\begin{array}{c}0.703^{* * *} \\
(6.69)\end{array}$ & $\begin{array}{c}0.618^{* * *} \\
(4.93)\end{array}$ & $\begin{array}{l}0.057 \\
(0.90)\end{array}$ \\
\hline $\begin{array}{l}N \\
\text { Adj. } R^{2}\end{array}$ & $\begin{array}{l}5527 \\
0.032\end{array}$ & $\begin{array}{l}6126 \\
0.068\end{array}$ & $\begin{array}{l}5527 \\
0.077\end{array}$ & $\begin{array}{l}6126 \\
0.037\end{array}$ \\
\hline
\end{tabular}

Note. ${ }^{*},{ }^{* *}$, and ${ }^{* * *}$ indicate significance at the confidence level of $10 \%, 5 \%$, and $1 \%$, respectively, and $t$-value statistics are in parentheses.

Media attention can influence the internal governance strategy of the company's management through the information dissemination mechanism and also can intimidate managers' behavior through the reputation mechanism, so that they can restrain the adjustment of the company's accounting information disclosure strategy. Based on the above analysis, this paper proposes the research Hypothesis 4 to be tested.

Hypothesis 4. The higher the media attention is, the more it can restrain the impact of managers' compensation on the degree of earnings management.
Media supervision refers to the way in which newspapers, journals, and other mass media disclose various illegal acts. Its supervision is directly proportional to the number of times reported by the media. To test this hypothesis, this paper selects the variable MEDIA as the natural logarithm of media reported times of sample companies from China Research Data Service Platform (CNRDS) from 2014 to 2018 as a proxy variable of media attention degree. The higher the value of MEDIA, the higher the media attention of the company. In order to ensure the reliability of the conclusion, after excluding multicollinearity, this paper introduces the interaction term of three variables and sets model (10) for regression test:

$$
\begin{aligned}
\mathrm{EM}= & \beta_{0}+\beta_{1} \mathrm{RP}+\beta_{2} \mathrm{ROA}+\beta_{3} \mathrm{MEDIA}+\beta_{4} \mathrm{RP} \times \mathrm{ROA}+\beta_{5} \mathrm{RP} \times \mathrm{MEDIA} \\
& +\beta_{6} \mathrm{ROA} \times \mathrm{MEDIA}+\beta_{7} \mathrm{RP} \times \mathrm{ROA} \times \mathrm{MEDIA}+\sum \mathrm{CONTROLS}+\varepsilon .
\end{aligned}
$$

As shown in Table 6, the coefficient of $\mathrm{RP} \times \mathrm{ROA} \times \mathrm{MEDIA}$ in Column (1) is -0.605 and significantly negative at the $1 \%$ level, indicating that media attention can inhibit the negative impact of the interaction between compensation level RP and corporate profitability ROA on earnings management DA of calculated items. In Column (2), the coefficient of $\mathrm{RP} \times \mathrm{ROA} \times \mathrm{MEDIA}$ is -1.147 and is significantly negative at the $1 \%$ level, indicating that media attention can also inhibit the negative impact of the interaction between compensation level RP and corporate profitability ROA on real project earnings management DA. The empirical results support Hypothesis 4. Media attention can restrain the earnings management behavior of well-paid managers of listed companies, reduce the damage caused by earnings management behavior of well-paid managers to investors' rights and interests, and give full play to its effective supervision role. On the one hand, the media can cause market pressure on the executives of listed companies through exposure or reports on listed companies and have an effective inhibiting effect on managers' behavior of manipulating earnings. On the other hand, regulators can effectively make use of the external governance effect of the media on listed companies, requiring the media to report the relevant information of listed companies regularly. While providing real and effective information for investors, it can also effectively weaken the earnings management behavior 
TABLE 5: Regression results of the model.

\begin{tabular}{|c|c|c|}
\hline Variables & $\begin{array}{l}(1) \\
\text { DA }\end{array}$ & $\begin{array}{c}(2) \\
\text { REM }\end{array}$ \\
\hline $\mathrm{RP}$ & $\begin{array}{l}0.008 \\
(0.82) \\
\end{array}$ & $\begin{array}{c}0.091^{* * *} \\
(4.20)\end{array}$ \\
\hline The $\mathrm{RP} \times \mathrm{ROA}$ & $\begin{array}{c}0.338^{* * *} \\
(3.62)\end{array}$ & $\begin{array}{c}2.104^{* * *} \\
(10.14)\end{array}$ \\
\hline $\mathrm{ROA}$ & $\begin{array}{c}0.758^{* * *} \\
(20.34)\end{array}$ & $\begin{array}{c}0.427^{* * *} \\
(5.14)\end{array}$ \\
\hline TOBINQ & $\begin{array}{c}0.002^{* * *} \\
(3.83)\end{array}$ & $\begin{array}{c}0.006^{* * *} \\
(6.47)\end{array}$ \\
\hline SIZE & $\begin{array}{c}0.002^{*} \\
(1.69)\end{array}$ & $\begin{array}{c}0.020^{* * *} \\
(7.92)\end{array}$ \\
\hline GROWTH & $\begin{array}{c}0.005^{* * *} \\
(7.82)\end{array}$ & $\begin{array}{c}0.010^{* * *} \\
(7.14) \\
\end{array}$ \\
\hline LEV & $\begin{array}{c}0.019^{* * *} \\
(2.97)\end{array}$ & $\begin{array}{c}0.218^{* * *} \\
(15.24)\end{array}$ \\
\hline BIG4 & $\begin{array}{c}0.021^{* * *} \\
(4.38)\end{array}$ & $\begin{array}{c}0.031^{* * *} \\
(2.88)\end{array}$ \\
\hline $\begin{array}{l}\text { INDUSTRY } \\
\text { YEAR }\end{array}$ & $\begin{array}{l}\text { Yes } \\
\text { Yes }\end{array}$ & $\begin{array}{l}\text { Yes } \\
\text { Yes }\end{array}$ \\
\hline Constant & $\begin{array}{c}0.060^{* *} \\
(2.26)\end{array}$ & $\begin{array}{c}0.319^{* * *} \\
(5.44)\end{array}$ \\
\hline $\begin{array}{l}N \\
\text { Adj. } R^{2}\end{array}$ & $\begin{array}{l}11653 \\
0.258\end{array}$ & $\begin{array}{l}11653 \\
0.083\end{array}$ \\
\hline
\end{tabular}

Note. $^{*},{ }^{* *}$, and ${ }^{* * *}$ indicate significance at the confidence level of $10 \%, 5 \%$, and $1 \%$, respectively, and $t$-value statistics are in parentheses.

TABLE 6: Regression results of model (10).

\begin{tabular}{|c|c|c|}
\hline Variables & $\begin{array}{l}(1) \\
\text { DA }\end{array}$ & $\begin{array}{c}(2) \\
\text { REM }\end{array}$ \\
\hline $\mathrm{RP}$ & $\begin{array}{c}0.147^{* * *} \\
(3.39) \\
\end{array}$ & $\begin{array}{l}0.146 \\
(1.51) \\
\end{array}$ \\
\hline ROA & $\begin{array}{l}0.142 \\
(0.64) \\
\end{array}$ & $\begin{array}{c}1.487^{* * *} \\
(3.01)\end{array}$ \\
\hline MEDIA & $\begin{array}{c}0.011^{* * *} \\
(3.06)\end{array}$ & $\begin{array}{c}0.021^{* * *} \\
(2.62)\end{array}$ \\
\hline The $\mathrm{RP} \times \mathrm{ROA}$ & $\begin{array}{c}2.653^{* * *} \\
(5.31) \\
\end{array}$ & $\begin{array}{c}3.669^{* * *} \\
(3.31) \\
\end{array}$ \\
\hline The $\mathrm{RP} \times \mathrm{MEDIA}$ & $\begin{array}{c}0.029^{* * *} \\
(3.46)\end{array}$ & $\begin{array}{c}0.010 \\
(0.53) \\
\end{array}$ \\
\hline ROA by MEDIA & $\begin{array}{c}0.183^{* * *} \\
(4.58)\end{array}$ & $\begin{array}{c}0.378^{* * *} \\
(4.28) \\
\end{array}$ \\
\hline The RP $*$ MEDIA ROA & $\begin{array}{c}0.605^{* * *} \\
(6.56)\end{array}$ & $\begin{array}{c}1.147^{* * *} \\
(5.61)\end{array}$ \\
\hline $\begin{array}{l}\text { CONTROLS } \\
\text { Constant }\end{array}$ & $\begin{array}{c}\text { Yes } \\
0.086^{* * *} \\
(2.79) \\
\end{array}$ & $\begin{array}{c}\text { Yes } \\
0.152^{* *} \\
(2.22)\end{array}$ \\
\hline $\begin{array}{l}N \\
\text { Adj. } R^{2}\end{array}$ & $\begin{array}{l}11653 \\
0.266 \\
\end{array}$ & $\begin{array}{l}11653 \\
0.100 \\
\end{array}$ \\
\hline
\end{tabular}

Note. ${ }^{*},{ }^{* *}$, and ${ }^{* * *}$ indicate significance at the confidence level of $10 \%, 5 \%$, and $1 \%$, respectively, and $t$-value statistics are in parentheses. 
of overpaid managers of listed companies that harm the interests of investors.

\section{Conclusion and Enlightenment}

Taking China's A-share listed companies from 2014 to 2018 as research samples, this paper studies the impact of executive compensation on earnings management from the perspective of corporate governance. The results show that, first, managers with high compensation level will conduct earnings management that is beneficial to the company while considering their own interests: if the executives of the company get high enough compensation and income during their tenure, they are more inclined to conduct earnings management behaviors that are beneficial to the company's interests. Second, for companies with strong profitability, the higher the manager's salary is, the more inclined he is to reduce the current accrued earnings to reduce taxes. For companies with weak profitability, managers with relatively high salaries tend to choose to increase real earnings to optimize financial indicators. This paper considers that the motivation of salary cannot effectively drive managers to conduct earnings management at the expense of the company under the condition that the well-paid managers are relatively satisfied with their own returns. Third, the strong pressure generated by media attention can make the wellpaid managers restrain the earnings management behaviors mentioned previously. In recent years, China's policies require governance of the compensation chaos in listed companies, and media supervision has effectively played the role of external governance, which becomes an effective way to protect investors' rights and interests.

\section{Data Availability}

The data used to support the findings of this study are available from the corresponding author upon request.

\section{Conflicts of Interest}

The authors declare that they have no conflicts of interest.

\section{Acknowledgments}

This work was supported by National Natural Science Foundation of China: corporate venture capital and technology innovation of the investing company: transmission mechanism, scenario dependence, and value effect (72172042), National Natural Science Foundation of China: the impact of accounting information quality on Enterprise Technological Innovation: mechanism, path, and value effect. (71672046), and National Natural Science Foundation of China: research on financial innovation and risk analysis theory under network big data environment (71532004).

\section{References}

[1] K. Schipper, "Earnings management," Accounting Horizons, vol. 3, p. 91, 1989.
[2] L. Xu, C. Liu, and X. Yang, "Pay dispersion within top management team and firm performance," Economic management, vol. 37, pp. 61-70, 2015.

[3] S. Liu and D. Wan, "Executive compensation affects firm performance: the empirical comparative study on state-owned and non-state-owned enterprises," China Soft Science, vol. 2, pp. 90-101, 2013.

[4] H. Luo, Y. L. Zeng, and L. Y. Wan, "Pay bandwagon, earnings management and executives' compensation manipulation," Nankai Business Review, vol. 19, pp. 19-31, 2016.

[5] Z. Yuan, W. Hao, and Z. Wang, "Empirical research about the influence of management incentives on the accrual earnings management and real earnings management," Management Review, vol. 26, pp. 181-196, 2016.

[6] P. Jongjaroenkamol and V. Laux, "Insider versus outsider CEOs, executive compensation, and accounting manipulation," Journal of Accounting and Economics, vol. 63, no. 2-3, pp. 253-261, 2017.

[7] G. Alisa, B. A. Gouldman, J. M. Rose, and K. Rotaru, "Effects of superiors' compensation structures on psychophysiological responses and real earnings management decisions of subordinate managers," Management Accounting Research, vol. $48,2020$.

[8] C. Gao and L. Hao, "The impact of expectation and competition on satisfaction and loyalty of employees," Chinese Journal of Management, vol. 7, pp. 103-110, 2010.

[9] M. Erickson, M. Hanlon, and E. L. Maydew, "How much will firms pay for earnings that do not exist? Evidence of taxes paid on allegedly fraudulent earnings," The Accounting Review, vol. 79, no. 2, pp. 387-408, 2004.

[10] Y. Wang, L. Wang, and C. Gong, "Reform of enterprise income tax, earnings management and its economic consequences," Economic Research Journal, vol. 44, pp. 86-98, 2009.

[11] Z. Li, Q. Zeng, and X. Wei, "Debt-covenant, controller's characteristic and earnings management," Economic Review, vol. 32, pp. 88-96, 2011.

[12] Z. Li, Y. Zheng, and Y. Lian, "Equity refinancing, earnings management and the performance decline of China listed companies: viewpoint from accruals and real activities manipulation," Chinese Journal of Management Science, vol. 19, pp. 49-56, 2011.

[13] F. Jiang, M. Zhang, Z. Lu, and C. Chen, "Management overconfidence, enterprise expansion and financial distress," Economic Research Journal, vol. 55, pp. 132-144, 2009.

[14] Y. Wang, H. Liu, and $\mathrm{L}$. Wu, "Information transparency, institutional investor and stock price comovement," Journal of Financial Research, vol. 52, pp. 162-174, 2009.

[15] S. Roychowdhury, "Earnings management through real activities manipulation," Journal of Accounting and Economics, vol. 42, no. 3, pp. 335-370, 2006.

[16] H. Luo and Y. Zeng, "On executive pay bandwagon and corporate tax avoidance," Journal of Zhongnan University of Economics and Law, vol. 31, pp. 3-13, 2018.

[17] L. Wu and Y. Wang, "Estimation model and empirical evidence of the extent of earnings management: a survey," Economic Research Journal, vol. 53, pp. 143-152, 2007.

[18] S. P. Kothari, A. J. Leone, and C. E. Wasley, "Performance matched discretionary accrual measures," Journal of Accounting and Economics, vol. 39, no. 1, pp. 163-197, 2005.

[19] D. Peña-Martel, J. Pérez-Alemán, and D. J. Santana-Martín, "The role of the media in creating earnings informativeness: evidence from Spain," BRQ Business Research Quarterly, vol. 21, no. 3, pp. 168-179, 2018. 
[20] F. Comiran, T. Fedyk, and J. Ha, "Accounting quality and media attention around seasoned equity offerings," International Journal of Accounting \& Information Management, vol. 26, no. 3, pp. 443-462, 2018. 